\title{
Calcitonin-Induced Effects on Amniotic Fluid-Derived Mesenchymal Stem Cells
}

\author{
Caterina Morabito ${ }^{a, b, c}$ Iolanda D'Alimonte ${ }^{b, c, d}$ Laura Pierdomenico ${ }^{b, c, e}$ \\ Caterina Pipino ${ }^{b, c, d}$ Simone Guarnieria,c Giusy A. Caprara ${ }^{a, c}$ Ivana Antonucci ${ }^{b, c, f}$ \\ Renata Ciccarellib,c,d Marco Marchisio ${ }^{b, c, e}$ Assunta Pandolfib,c,d Maria A. Mariggiòo ${ }^{a, b, c}$ \\ aDepartment of Neuroscience, Imaging and Clinical Sciences, 'G. d'Annunzio' University of Chieti- \\ Pescara, Chieti, 'bStemTeCh Group, Chieti, 'Centre for Aging Sciences (Ce.S.I), 'G. d'Annunzio' University \\ Foundation, Chieti, 'Department of Medical, Oral, and Biotechnological Sciences, 'G. d'Annunzio' \\ University of Chieti-Pescara, Chieti, 'Department of Medicine and Aging Sciences,'G. d'Annunzio' \\ University of Chieti-Pescara, Chieti, 'Department of Psychological Sciences, Humanities and Territory, \\ 'G. d'Annunzio' University of Chieti-Pescara, Chieti, Italy
}

\section{Key Words}

Calcitonin • Calcitonin receptor $\bullet$ Mesenchymal stem cells $\bullet$ Human amniotic fluid $\bullet$ Osteogenesis

\begin{abstract}
Background/Aims: Mesenchymal stem cells from human amniotic fluid (huAFMSCs) can differentiate into multiple lineages and are not tumorigenic after transplantation, making them good candidates for therapeutic purposes. The aim was to determine the effects of calcitonin on these huAFMSCs during osteogenic differentiation, in terms of the physiological role of calcitonin in bone homeostasis. Methods: For huAFMSCs cultured under different conditions, we assayed: expression of the calcitonin receptor, using immunolabelling techniques; proliferation and osteogenesis, using colorimetric and enzymatic assays; intracellular $\mathrm{Ca}^{2+}$ and cAMP levels, using videomicroscopy and spectrophotometry. Results: The calcitonin receptor was expressed in proliferating and osteo-differentiated huAFMSCs. Calcitonin triggered intracellular $\mathrm{Ca}^{2+}$ increases and cAMP production. Its presence in cell medium also induced dose-dependent inhibitory effects on proliferation and increased osteogenic differentiation of huAFMSCs, as also indicated by enhancement of specific markers and alkaline phosphatase activity. Conclusions: These data show that huAFMSCs represent a potential osteogenic model to study in-vitro cell responses to calcitonin (and other members of the calcitonin family). This leads the way to the opening of new lines of research that will add new insight both in cell therapies and in the pharmacological use of these molecules.
\end{abstract}




\section{Cellular Physiology Cell Physiol Biochem 2015;36:259-273 \\ \begin{tabular}{l|l} 
and Biochemistry Published online: May 04, 2015 & $\begin{array}{l}\text { C 2015 S. Karger AG, Basel } \\
\text { www.karger.com/cpb }\end{array}$ \\
\hline
\end{tabular} \\ Morabito et al.: Calcitonin and Osteogenesis}

\section{Introduction}

Mesenchymal stem cells (MSCs) have high capacity for self-renewal and the potential to differentiate along different lineages, and thus they represent a useful tool for cellular therapies [1-3]. In particular, bone-marrow-derived MSCs have now been used clinically to repair bone defects $[4,5]$. In recent years, different studies have showed that human amniotic fluid provides a good and more easily accessible source of MSCs that show very low risk of tumour development, and no evident antigenicity [6,7]. These human amniotic fluid MSCs (huAFMSCs) can differentiate into osteoblastic cells [8], and when seeded onto scaffolds and cultured in osteogenic inductive medium, they support the formation of highly mineralised tissue after implantation in animal models [9-12]

Bone regeneration after traumatic or degenerative damage requires interactions between cells and growth factors and the extracellular matrix. Among the growth factors that modulate bone physiology, calcitonin (CT) has an important role in bone remodelling, as it acts on osteoblasts (bone-forming cells) and osteoclasts (bone-resorbing cells) [13-15]. CT functions through limiting the number of osteoclasts and inhibiting their motility and secretory activity $[16,17]$, and by inducing a burst of proliferation and functional activation of osteoblasts $[18,19]$. Farley and colleagues reported direct effects of CT on different osteoblastic cell models: i.e., murine bone cells [20], human osteosarcoma (SAOS-2, TE-85) cells, and normal human osteoblast-like cells isolated from the head of the femur [21, 22]. CT has also been reported to prevent osteoblast and osteocyte apoptosis in murine cell lines and primary cultures of osteoblast-like cells, which appears to occur via actions mediated by receptors linked to the adenylyl cyclase system [23]. Despite this evidence, the direct effects of CT on osteoblasts are controversial and not fully clear [17].

The biological activities of CT are mediated by its binding to a specific receptor, the CT receptor (CTR), which belongs to the family of seven-transmembrane-domain G-proteincoupled receptors [24]. In human, there are different CTR isoforms that are derived from alternative splicing of the primary transcript of a single gene (CALCR) [25].

Calcitonin-induced activation of the CTR triggers multiple signal transduction pathways that include stimulation of the activities of both adenylyl cyclase/cAMP/protein kinase A (PKA) and phospholipase $\mathrm{C}$, which, in turn, promotes the release of $\mathrm{Ca}^{2+}$ from intracellular stores and the influx of extracellular $\mathrm{Ca}^{2+}[16,26,27]$.

Although these signalling pathways have been demonstrated to be mediated by direct binding of the hormone CT to the CTR expressed by osteoclasts [28], the presence of the CTR in osteoblasts still remains unclear and controversial, as well as which signalling cascade is activated by CT $[18,29]$. It has been reported that there are CTR-mediated effects in osteoblastic cell lines and primary cultures of osteoblast-like cells of rodent [30-32], and human $[22,29,33]$ origins; on the other hand, Naot and Cornish showed high levels of CTR-like receptor, but no expression of the CTR, in human primary osteoblasts [24]. The variability of the available data might be dependent on the complexity of the CT/CTR system, the variety of CT-family factors, the several patterns of receptor expression and assembly in cell lines, and the different experimental models used [24].

In the present study, we aimed to define the involvement of the CTR and early events that are triggered by its activation by human CT in osteoblastic-like cells derived from huAFMSCs, a model known to be induced towards osteogenic differentiation [8].

\section{Materials and Methods}

\section{Chemicals and materials}

Unless otherwise indicated, the cell culture media, sera and antibiotics were from Life Technologies Italia (Monza, Italy), the cell culture plasticware was from Becton Dickinson Falcon ${ }^{\mathrm{TM}}$ (Sacco Srl, Cadorago, Italy), and the reagents and standards were from Sigma-Aldrich (Milan, Italy). Human CT was from SigmaAldrich. 


\section{Cellular Physiology Cell Physiol Biochem 2015;36:259-273 \begin{tabular}{l|l|l} 
and $10.1159 / 000374069$ & & $\begin{array}{l}\text { O 2015 S. Karger AG, Basel } \\
\text { www.karger.com/cpb }\end{array}$ \\
\hline
\end{tabular} \\ Morabito et al.: Calcitonin and Osteogenesis}

Cell culture

Human amniotic fluid (huAF) samples (2-3 ml) were obtained from 16-to-19-week pregnant women who underwent amniocentesis for prenatal diagnosis. All of the patients received detailed information about the experimental protocol, which was approved by the Ethics Committee of the University of ChietiPescara, and each participant gave her written informed consent.

The cells were immediately isolated from the huAF by centrifugation at $150 \times g$ for $10 \mathrm{~min}$ at room temperature. The cell pellet was resuspended in $5 \mathrm{ml}$ low-glucose Dulbecco's modified Eagle's medium with $20 \%$ foetal bovine serum, $4 \mathrm{mM}$ L-glutamine, $100 \mathrm{IU} / \mathrm{ml}$ penicillin, $100 \mu \mathrm{g} / \mathrm{ml}$ streptomycin, and 5 $\mathrm{ng} / \mathrm{ml} \beta$-fibroblast growth factor, seeded into a $\mathrm{T}_{25}$ tissue culture flask, and incubated at $37{ }^{\circ} \mathrm{C}$ in a $5 \%$ $\mathrm{CO}_{2}$ humidified atmosphere. The medium and non-adherent cells were removed after 7 days, and then the medium was changed every 3 to 4 days. The huAFMSCs were allowed to expand to $70 \%$ confluence and then routinely subcultured at 1:3 dilution. The huAFMSCs were maintained in culture for up to 6 to 8 passages, and used for all of the experiments [8].

\section{Immunophenotyping of huAFMSCs}

To analyse the expression of typical cell surface and intracellular protein markers, huAFMSCs were stained with anti-human primary antibodies, as previously described [8,34]. Briefly, $5 \times 10^{5}$ cells/sample were incubated with $100 \mu \mathrm{l} 20 \mathrm{mM}$ ethylenediaminetetraacetic acid (EDTA) at $37^{\circ} \mathrm{C}$ for $10 \mathrm{~min}$, and then washed. Washing buffer (phosphate-buffered saline [PBS], $0.1 \%$ sodium azide, $0.5 \%$ bovine serum albumin) was used for all of the washing steps ( $3 \mathrm{ml}$ washing buffer, with centrifugation at $400 \times g$ for 8 min at 4 ${ }^{\circ} \mathrm{C}$ ). Fluorescein-isothiocyanate-conjugated (FITC) anti-CD13, anti-CD44, anti-CD45, anti-CD105 and antiCD166 antibodies, and phycoerythrin-conjugated anti-CD29 (anti-CD29-PE) antibodies were from Ancell (MN, USA); anti-CD14-FITC was from Miltenyi Biotec (Bergisch Gladbach, Germany); anti-CD90-FITC, anti-CD73-PE, anti-Sox2-Alexa488-conjugated, anti-SSEA4-FITC, anti-CD146-PE, anti-OCT3/4-PE and antiCD117-allophycocyanin-conjugated (CD117-APC) were from Becton Dickinson (San Jose, CA, USA); antiCD144-FITC was from Acris Antibodies (Herford, Germany); anti-CD34-PE was from Beckman Coulter (Fullerton, CA, USA); the anti-hTERT primary antibody was from Calbiochem (Dermastadt, Germany), and the appropriate secondary FITC-conjugated antibody was from Jackson Immuno Research Laboratories (West Grove, PA, USA).

To stain the surface antigens, a cell pellet was added to $100 \mu$ l washing buffer containing the appropriate amount of surface antibody. The samples were then incubated for $30 \mathrm{~min}$ at $4{ }^{\circ} \mathrm{C}$ in the dark. To stain the intracellular antigens, $1 \mathrm{ml}$ Perm 2 (Becton Dickinson) was added to each tube and the cells were incubated for $10 \mathrm{~min}$ at room temperature in the dark. The samples were washed and resuspended in $100 \mu \mathrm{l}$ washing buffer containing the appropriate amount of intracellular antibody, and incubated for 30 $\min$ at $4{ }^{\circ} \mathrm{C}$ in the dark. At the end of this incubation, the cells were washed, centrifuged, resuspended in $0.5 \%$ paraformaldehyde, incubated for $5 \mathrm{~min}$ at room temperature, washed, centrifuged again and kept at $4{ }^{\circ} \mathrm{C}$ in the dark until analysis using a FACSCalibur flow cytometer (Becton Dickinson) and the CellQuest ${ }^{\mathrm{TM}}$ 3.2.1.f1 software (Becton Dickinson). Quality control was performed using a regular check with Rainbow Calibration Particles (Becton Dickinson Biosciences). Debris was excluded from the analysis by gating on the morphological parameters, and 20,000 non-debris events in the morphological gate were recorded for each sample. To assess the non-specific fluorescence, we used isotype controls. All of the antibodies were titrated under assay conditions and optimal photomultiplier voltages were established for each channel. The data were analysed using the Flow $\mathrm{Jo}^{\mathrm{TM}}$ software (TreeStar, Ashland, OR, USA). The mean fluorescence intensity (MFI) ratio was calculated by dividing the MFI of positive events by the MFI of negative events.

Osteogenic differentiation

After seeding, the huAFMSCs were maintained for 3 days in normal medium, which was then substituted with osteogenic differentiation medium that included Dulbecco's modified Eagle's medium, 10\% foetal bovine serum, $4 \mathrm{mM}$ L-glutamine, $100 \mathrm{IU} / \mathrm{ml}$ penicillin, $100 \mu \mathrm{g} / \mathrm{ml}$ streptomycin, $0.05 \mathrm{mM}$ ascorbic acid, $10 \mathrm{mM} \beta$-glycerophosphate, $100 \mathrm{nM}$ dexamethasone, for 7, 14 or 21 days, with changes of medium every 3 days. Mineralisation was evaluated according to alkaline phosphatase (ALP) activity, alizarin red S staining assays and von Kossa staining.

Alkaline phosphatase activity assay

Alkaline phosphatase activity was determined as previously reported [8]. Briefly, cell monolayers were washed with PBS, lysed with $1 \mathrm{ml}$ Tris buffer (10 mM Tris, pH 7.5, 0.1\% Triton X-100) and centrifuged KARGER 


\section{Cellular Physiology Cell Physiol Biochem 2015;36:259-273 \begin{tabular}{l|l} 
and Biochemistry Published online: May 04, 2015 & $\begin{array}{l}\text { Co 2015 S. Karger AG, Basel } \\
\text { www.karger.com/cpb }\end{array}$ \\
\hline
\end{tabular} \\ Morabito et al.: Calcitonin and Osteogenesis}

(2,000 rpm for $1 \mathrm{~min}$ ). Then, $20 \mu \mathrm{l}$ of the supernatant from each sample was combined with $20 \mu \mathrm{l} 1 \mathrm{mM}$ p-nitrophenyl phosphate ( $\mathrm{pH} 10.3$,in $\mathrm{MgCl}_{2}$-diethanolamine buffer), as substrate, and dispensed into 96-well plates. The samples were incubated for $30 \mathrm{~min}$ at room temperature in the dark. The reaction was stopped with the addition of $10 \mu \mathrm{l} 2 \mathrm{~N} \mathrm{NaOH}$ to each well. The amount of p-nitrophenyl phosphate released was measured as absorbance at $405 \mathrm{~nm}$ using a microplate spectrophotometer (Spectramax SM190; Molecular Devices, Sunnyvale, CA, USA). The protein content of each sample was determined using the BioRad protein assay (Bio-Rad Laboratories, Milan, Italy). The enzyme activity was expressed as nmoles p-nitrophenyl phosphate released per mg protein per $30 \mathrm{~min}$.

\section{Alizarin red S staining}

Visualisation of calcium deposition and extracellular matrix mineralisation of huAMSCs after 7, 14 and 21 days in osteogenic differentiation medium was obtained using alizarin red S staining. The samples were stained following the procedure described by D'Alimonte and colleagues [8], and then visualised using a phase-contrast microscope (Eclipse TS100; Nikon Instruments S.p.A, Campi Bisenzio FI, Italy) equipped with a digital camera (D200; Nikon).

\section{Von Kossa staining}

The cells were washed three times with PBS and fixed in 4\% paraformaldehyde for 15 min at room temperature. After washing five times with distilled water, the samples were incubated with $5 \%$ silver nitrate (Sigma-Aldrich) and exposed to UV light for $60 \mathrm{~min}$. Then, the cells were washed five times with distilled water, incubated with 5\% sodium thiosulphate (Sigma-Aldrich) for 2 min, and washed three times with distilled water. Calcium-phosphate deposits were stained black. The complete stained plates were scanned using Image Scanner (GE Healthcare, Milan, Italy) and densitometric analysis was performed with Image Raster 2d Platinum 7.0 (GE Healthcare).

\section{RNA isolation and real-time PCR analysis}

Osteogenic markers were evaluated using real-time PCR. Total RNA was isolated using RNeasy Plus Universal Mini kits (Qiagen Inc., Valencia, CA, USA), according to the manufacturer instructions. The M-MLV Reverse Transcriptase reagents (Applied Biosystems) were used to generate cDNA. Real-time PCR was carried out with the ABI Prism 7900 Sequence Detection System (Applied Biosystems, Foster City, CA, USA). The expression levels of Runt-related transcription factor-2 (Runx2), osteopontin and osteocalcin were evaluated after 3, 4 and 14 days in cells cultured in normal medium or in osteo-differentiating medium, in the absence and presence of CT. Commercially available TaqMan Gene Expression Assays (Runx2 Hs00231692_m1; BGLAP (OCN) Hs01587814_g1; SPP (OPN) Hs00959010_m1) and the TaqMan Universal PCR Master Mix (Applied Biosystems, Foster City, CA, USA) were used according to standard protocols. Beta-2 microglobulin (B2M Hs99999907_m1) (Applied Biosystems) was used for template normalisation. Duplicate determinations were carried out for each sample.

\section{Western blotting}

Undifferentiated huAFMSCs and osteoblastic differentiated cells were lysed in cell lysis buffer (50 mM Tris-HCl, pH 7.4, 100 mM NaCl, 50 mM NaF, 40 mM $\beta$-glycerophosphate, 5 mM EDTA, 1\% [v/v] Triton X-100). The cells were sonicated and then centrifuged $\left(1,000 \times \mathrm{g}, 10 \mathrm{~min}, 4^{\circ} \mathrm{C}\right)$, the supernatants were collected, and the protein concentrations were determined using the Bio-Rad protein assay (Bio-Rad Laboratories). Samples $(50 \mu \mathrm{g}$ protein) were suspended in Laemmli buffer $(8 \%[\mathrm{w} / \mathrm{v}] \mathrm{SDS}, 10 \%$ [v/v] glycerol, $5 \%$ [v/v] $\beta$-mercaptoethanol, $25 \mathrm{mM}$ Tris-HCl, $\mathrm{pH} 6.5,0.003 \%$ [w/v] bromophenol blue), boiled (5 min), and separated on $10 \%(\mathrm{w} / \mathrm{v})$ homogeneous SDS-PAGE gels. The proteins were blotted onto nitrocellulose membranes (Hybond ${ }^{\mathrm{TM}}$-ECL membranes; Amersham, GE Healthcare, Milan, Italy) that were blocked in TBS-T (Tris-buffered saline with $0.1 \%$ [v/v] Tween 20$)$ containing $5 \%(\mathrm{w} / \mathrm{v})$ fat-free milk, incubated with a rabbit polyclonal antibody against the CTR (Abcam, Cambridge, UK; dilution 1:1,000), and then incubated with the relevant horseradish-peroxidase-conjugated antibody, and detected by chemiluminescence (Pierce ECL Plus; Thermo Scientific, Rockford, USA). The blots were stripped with $1 \%(\mathrm{v} / \mathrm{v}$ ) $\beta$-mercaptoethanol, $2 \%$ (w/v) SDS, in $60 \mathrm{mM}$ Tris- $\mathrm{HCl}$ (pH 6.8) for $30 \mathrm{~min}$ at $50^{\circ} \mathrm{C}$, washed, and re-probed with an anti-actin antibody (Sigma-Aldrich; dilution 1:1,000) and incubated with the relevant horseradish-peroxidase-conjugated antibody, and detected by chemiluminescence (Pierce ECL Plus). All of the antibodies were diluted in TBS-T. 


\section{Cellular Physiology Cell Physiol Biochem 2015;36:259-273 \begin{tabular}{l|l} 
and Biochemistry Published online: May 04, 2015 & $\begin{array}{l}\text { C 2015 S. Karger AG, Basel } \\
\text { www.karger.com/cpb }\end{array}$ \\
\hline
\end{tabular} \\ Morabito et al:: Calcitonin and Osteogenesis}

Immunostaining assay

Undifferentiated huAFMSCs and osteoblastic differentiated cells were plated onto 12-mm glass coverslips and were fixed in 4\% paraformaldehyde in PBS for $15 \mathrm{~min}$. After fixing, the samples were washed three times in PBS and incubated in $0.2 \%$ Triton X-100 for $10 \mathrm{~min}$, and then in blocking buffer (PBS plus $10 \%$ goat serum) for $1 \mathrm{~h}$ at room temperature, followed by an overnight incubation at $4^{\circ} \mathrm{C}$ with a rabbit polyclonal anti-CTR antibody (Abcam; dilution 1:500). The CTR was revealed using an Alexa-Fluor-488conjugated goat anti-rabbit secondary antibody (Life Technologies, Monza, Italy) with a $2 \mathrm{~h}$ incubation at room temperature. Images were acquired using a Zeiss LSM510 META system (Jena, Germany) equipped with a Zeiss Axiovert 200 inverted microscope and a Plan Neofluar oil-immersion objective (40×). Negative controls for each immunostaining assay were performed by immunolabelling a sample with only the secondary antibody [35].

\section{Intracellular cAMP measurements}

The intracellular cAMP levels were determined using the cAMP biotrak enzyme immunoassay system (Amersham,GE Healthcare), according to the manufacturer instructions. The cAMP levels of undifferentiated huAFMSCs and osteoblastic differentiated cells $(10,000$ cells/sample) without CT (indicated as $0 \mathrm{nM})$ or stimulated with 1 or $100 \mathrm{nM} \mathrm{CT}$, were calculated using a standard curve that ranged from 10 fmol to $10^{3}$ fmol cAMP [36].

\section{Intracellular Ca2+ measurements}

The intracellular $\mathrm{Ca}^{2+}$ analysis was performed on the undifferentiated huAFMSCs and osteoblastic differented cells plated using specific 96-well plates (2,000/well; Costar 3614, Corning Inc, NY, USA). The cells were incubated $\left(45 \mathrm{~min}, 37^{\circ} \mathrm{C}\right)$ in normal extracellular solution $(125 \mathrm{mM} \mathrm{NaCl}, 5 \mathrm{mMKCl}, 1 \mathrm{mM}$ $\mathrm{MgSO}_{4}, 1 \mathrm{mM} \mathrm{KH}_{2} \mathrm{PO}_{4}, 5.5 \mathrm{mM}$ glucose, $2 \mathrm{mM} \mathrm{CaCl}, 20 \mathrm{mM}$ HEPES, pH 7.4) supplemented with $10 \mathrm{mg} / \mathrm{ml}$ bovine serum albumin and $5 \mu \mathrm{M}$ Fura2-AM (Molecular Probes, Life Technologies). The Fura2-loaded cells were sequentially and repetitively excited at $340 \mathrm{~nm}$ and $380 \mathrm{~nm}$ using a high-speed wavelength switcher (Polychrome II; Till Photonics, Germany) equipped with a 75-W stabilised xenon lamp (Ushio Inc., Japan). The fluorescence images were collected using a 40× oil objective lens, acquired using a C6790 cooled CCD camera (Hamamatsu Photonics, Hamamatsu, Japan), and stored on an interfaced computer. The acquisition time was one image ratio per second. The graphs represent the temporal plots of the mean values of the single-cell fluorescence signals calculated from the image of the 340/380 ratio [37].

MTT assay

Cell growth was evaluated using the 3-(4,5-dimethylthiazol-2-yl)-2,5-diphenyl-tetrazolium bromide (MTT) assay. The cells were seeded in 96-well plates, and after $24 \mathrm{~h}$ they were left unstimulated or stimulated with $0.1 \mathrm{nM}, 1 \mathrm{nM}, 10 \mathrm{nM}$ and $100 \mathrm{nM}$ human CT in growth and osteogenic differentiation medium. Cell proliferation was followed for 7 days. At the time indicated, MTT was added to each well to a final concentration of $0.5 \mathrm{mg} / \mathrm{ml}$. The plates were incubated for $3 \mathrm{~h}$ at $37{ }^{\circ} \mathrm{C}$, and then centrifuged at $500 \times$ $g$ for $10 \mathrm{~min}$. The supernatant was removed, and $200 \mu \mathrm{l}$ dimethyl sulphoxide was added to each well. After incubation for $30 \mathrm{~min}$ at $37^{\circ} \mathrm{C}$, the plates were read at $560 \mathrm{~nm}$ in a spectrophotometer (Spectramax SM190). The cell numbers were determined from the optical density values obtained using a standard curve [38].

\section{Statistical analyses}

Experimental values are expressed as means \pm SEM. Statistical significance was assessed using Student's t-tests with the Prism5 software (GraphPad, San Diego, CA, USA). P values $<0.05$ were considered statistically significant.

\section{Results}

HuAFMSCs were isolated in the laboratory and tested for markers and their ability to undergo osteogenic differentiation. As expected, and as previously reported [8], these huAFMSCs did not show surface expression of haematopoietic markers (e.g., CD14, CD34, 
a

\begin{tabular}{|c|c|c|}
\hline \multicolumn{3}{|c|}{ Table Phenotype huAFMSCs } \\
\hline Antigens & Phenotype & MFI ratio \pm SD \\
\hline CD13 & + & $3.9 \pm 1.6$ \\
\hline $\mathrm{CD} 14$ & - & $1.1 \pm 0.1$ \\
\hline CD29 & +++ & $63.7 \pm 10.1$ \\
\hline CD34 & - & $1.1 \pm 0.1$ \\
\hline CD44 & +++ & $58.4 \pm 8.9$ \\
\hline CD45 & - & $1.0 \pm 0.1$ \\
\hline CD73 & ++ & $15.9 \pm 9.4$ \\
\hline CD90 & + & $6.5 \pm 2.7$ \\
\hline $\mathrm{CD} 105$ & + & $3.0 \pm 0.3$ \\
\hline CD117 & - & $1.1 \pm 0.3$ \\
\hline CD144 & - & $1.3 \pm 0.2$ \\
\hline CD146 & ++ & $35.8 \pm 12.7$ \\
\hline CD166 & + & $16.2 \pm 2.5$ \\
\hline HLA-ABC & ++ & $45.7 \pm 9.9$ \\
\hline HLA-DR & - & $1.1 \pm 0.1$ \\
\hline OCT3/4 & + & $3.4 \pm 0.2$ \\
\hline SSEA-4 & ++ & $49.6 \pm 20$ \\
\hline Sox-2 & +++ & $76.7 \pm 18.3$ \\
\hline h-TERT & +++ & $80.9 \pm 17.3$ \\
\hline $\begin{array}{l}-\quad \text { negative } \\
\text { expression; + } \\
\text { MFI ratio i } \\
\text { biological } \\
\text { positivity }>2 \\
\end{array}$ & $\begin{array}{r}\text { expression } \\
+ \text { positive; ++ } \\
\text { S the averag } \\
\text { amples } \pm \text { SD }\end{array}$ & $\begin{array}{l}+\quad+\text { moderate } \\
+ \text { high expression } \\
\text { e of } 3 \text { differen } \\
\text { Cut-off ratio }\end{array}$ \\
\hline
\end{tabular}

b
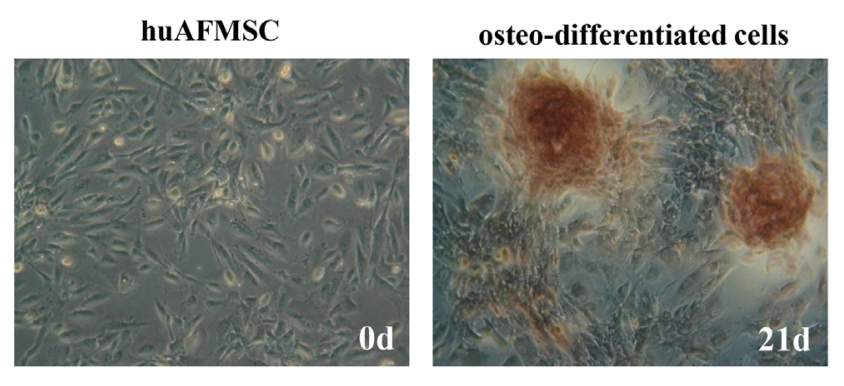

c

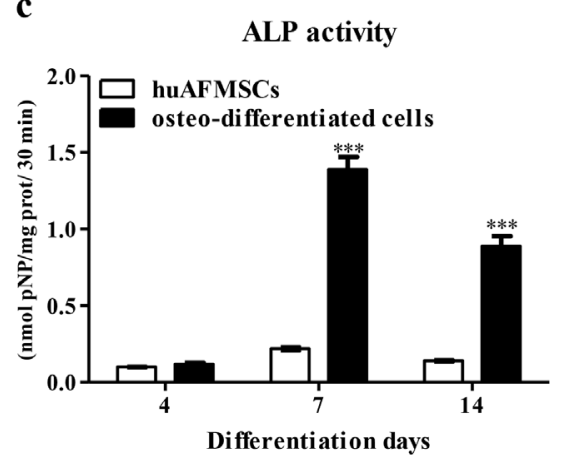

Fig. 1. Immunophenotyping and osteogenic differentiation of huAFMSCs. a. Cytofluorimetric analyses of the immunophenotypic profile of the huAFMSCs. b, c. Osteogenic differentiation of the huAFMSCs grown for 4-7-14 and 21 days in either growth or osteogenic medium, revealed by extracellular matrix mineralization assayed by alizarin Red S staining, (representative images in b), and by ALP activity (c). The images in (b) were acquired with a $20 \times$ objective lens. Data for quantification are means \pm S.E.M. of three independent experiments. ${ }^{* * *} \mathrm{p}<0.001$.

CD45), but expressed a variety of established mesenchymal markers (e.g., CD73, CD90, CD105), several related surface adhesion molecules (e.g., CD29, CD44, CD146, CD166), and the stemness markers hTERT, Sox-2, Oct3/4 and SSEA-4. They did not express CD117 (Fig. 1a). When incubated in osteogenic medium, these huAFMSCs showed increased extracellular calcium deposits (mineralisation) and ALP activity (Fig. 1b, c).

Considering the physiological role of CT on bone activity, and to evaluate any effects induced by CT on huAFMSCs, the expression and localisation of the CTR were determined for non-differentiated huAFMSCs and osteo-differentiated cells using Western blotting and immunofluoresce analysis. In addition, in all of the experiments, the same cell suspension was used to establish the control non-differentiated huAFMSCs and the osteo-differentiated cells maintained for the same incubation times in growth medium and osteogenic medium, respectively. As shown in Figure 2a, the lysates from the huAFMSCs maintained in growth medium and from the cells maintained in osteogenic differentiation medium for 21 days were probed with an anti-CTR antibody, which revealed immunoreactive bands that were consistent with the expression of the non-glycosylated and glycosylated CTR forms, at about $60 \mathrm{kDa}$ and $80 \mathrm{kDa}$, respectively [39]. The expression levels of the $60 \mathrm{kDa}$ CTR were greater than those of the $80 \mathrm{kDa}$ CTR in both cell models, and the densitometric analyses revealed a slight, but not significant, decrease in the ratio between the optical densities of the $60 \mathrm{kDa}$ and $80 \mathrm{kDa}$ CTR bands in the osteo-differentiated cells, in comparison to the huAFMSCs (Fig. 2b). The same Western blot (Fig. 2a) shows the negative control that did not express the CTR, as a monocyte/macrophage mouse cell line (Raw 264.7 cells), and the positive control of extracts from mouse kidney. 
Fig. 2. CTR expression. a. Representative Western blot of CTR levels in non-differentiated huAFMSCs, osteo-differentiated cells, RAW 264.7 murine cells (negative control) and mouse kidney lysate (positive control). b. Densitometric analyses of huAFMSCs and osteo-differentiated cell samples, quantified as the ratio between the $60 \mathrm{kDa}$ (non-glycosylated CTR form) and $80 \mathrm{kDa}$ (glycosylated CTR form) optical density bands. Data for quantification are means \pm S.E.M. from three independent experiments. c. Representative confocal microscopy images of non-differentiated huAFMSCs and osteo-differentiated cells (as indicated) stained with the anti-CTR antibody. Arrowheads CTR localization in the cytoplasmic compartment and near the plasmamembrane, in both phenotypes. Scale bars, $20 \mu \mathrm{m}$.

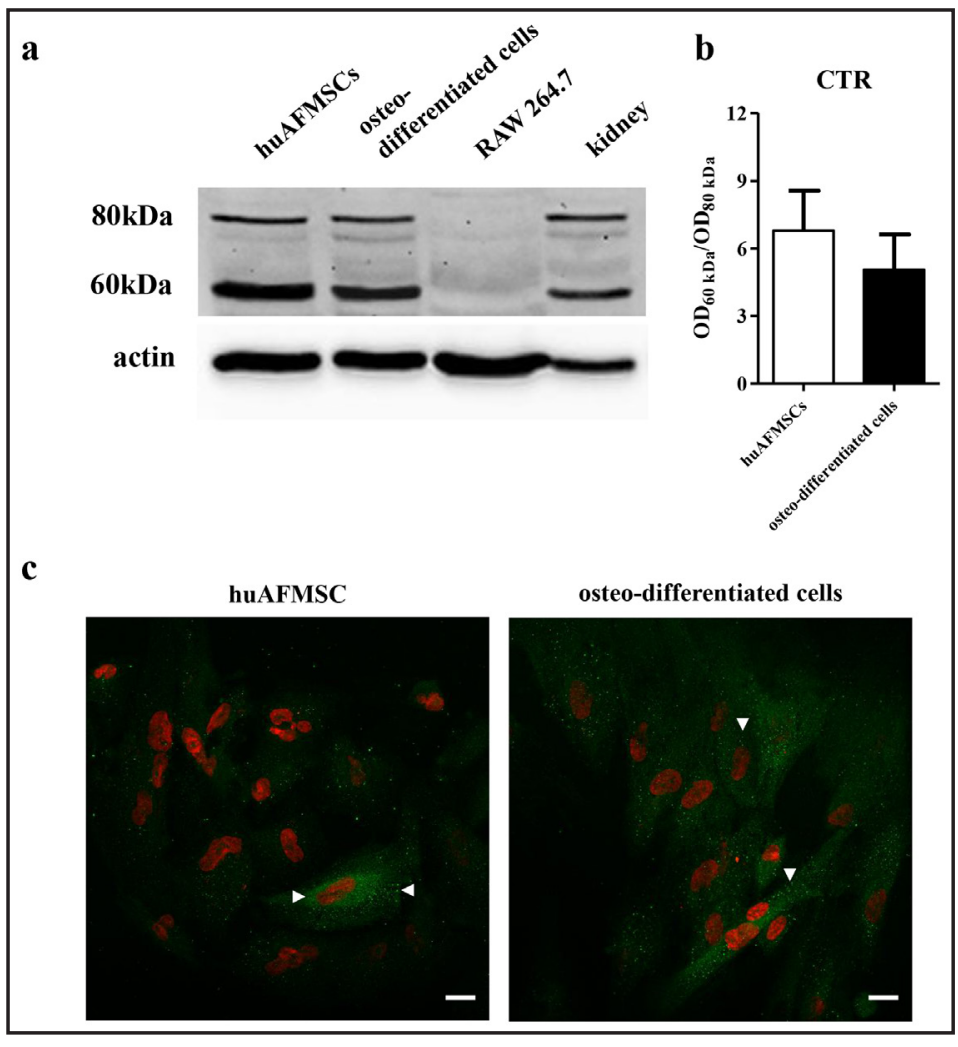

a

$1 \mathrm{nM}$

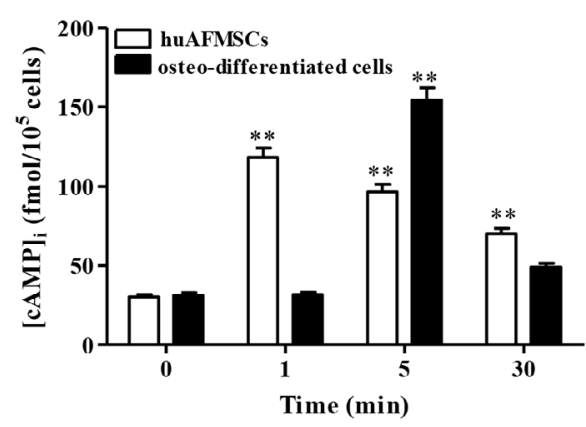

b

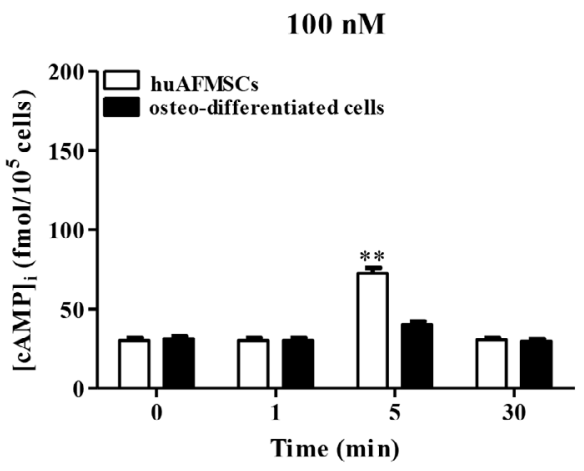

Fig. 3. CT-induced intracellular cAMP production. a, b. Quantification of cAMP levels in non-differentiated huAFMSCs and osteo-differentiated cells stimulated with $1 \mathrm{nM} \mathrm{CT}$ (a) and $100 \mathrm{nM} \mathrm{CT}$ (b) for 0, 1, 5, $30 \mathrm{~min}$. Data are means \pm S.E.M. from three independent experiments. ${ }^{* *} \mathrm{p}<0.005$ vs 0 min.

The CTR localisation was detectable for the cytoplasmic compartment and near the plasmamembrane in both the huAFMSCs and osteo-differentiated cells (Fig. 2c). Immunofluorescence analyses revealed that there was CTR immunoreactivity in about $20 \%$ of the cell populations, both for the huAFMSCs and osteo-differentiated cells.

It is known that binding of CT to the CTR activates the adenylyl cyclase/cAMP/PKA pathway and/or phospholipase $\mathrm{C}$, which in turn leads to protein kinase $\mathrm{C}$ activation/ $\mathrm{Ca}^{2+}$ mobilisation $[16,18]$. To determine the main pathway activated by this CT stimulation of the huAFMSCs and osteo-differentiated cells, the cAMP and intracellular $\mathrm{Ca}^{2+}$ levels were measured after $1 \mathrm{nM}$ and $100 \mathrm{nM}$ human CT stimulation (Figs. 3 and 4).

CT administration to these cell models induced increased intracellular cAMP levels (Fig. 3). At the low CT concentration (1 nM) there was a rapid and sustained (although 
a

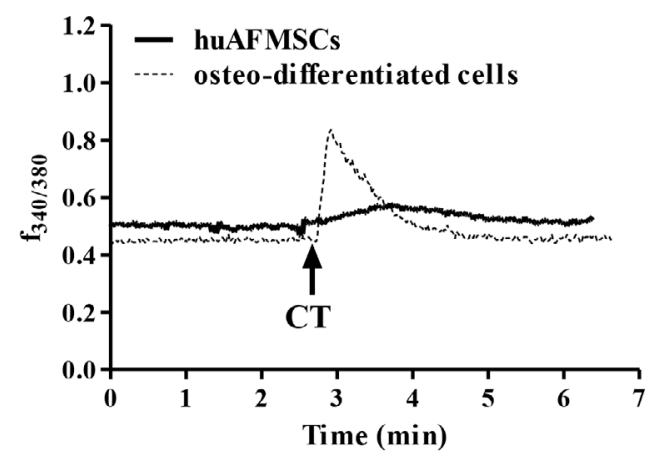

b

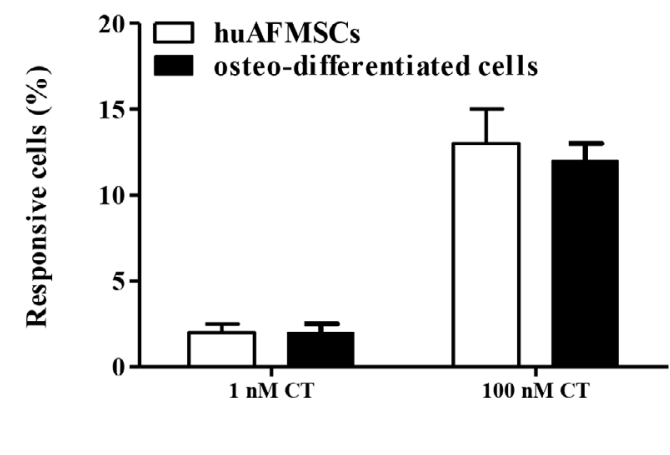

Fig. 4. CT-induced intracellular $\mathrm{Ca}^{2+}$ response. a. Representative traces of intracellular $\mathrm{Ca}^{2+}$ levels in non-differentiated huAFMSCs and osteo-differentiated cells stimulated with $1 \mathrm{nM}$ and $100 \mathrm{nM}$ CT. b. Quantification of cells responsive to $1 \mathrm{nM}$ and $100 \mathrm{nM}$ CT. Data are means \pm S.E.M. from 285 non-differentiated huAFMSCs and 253 osteo-differentiated cells from three independent experiments.

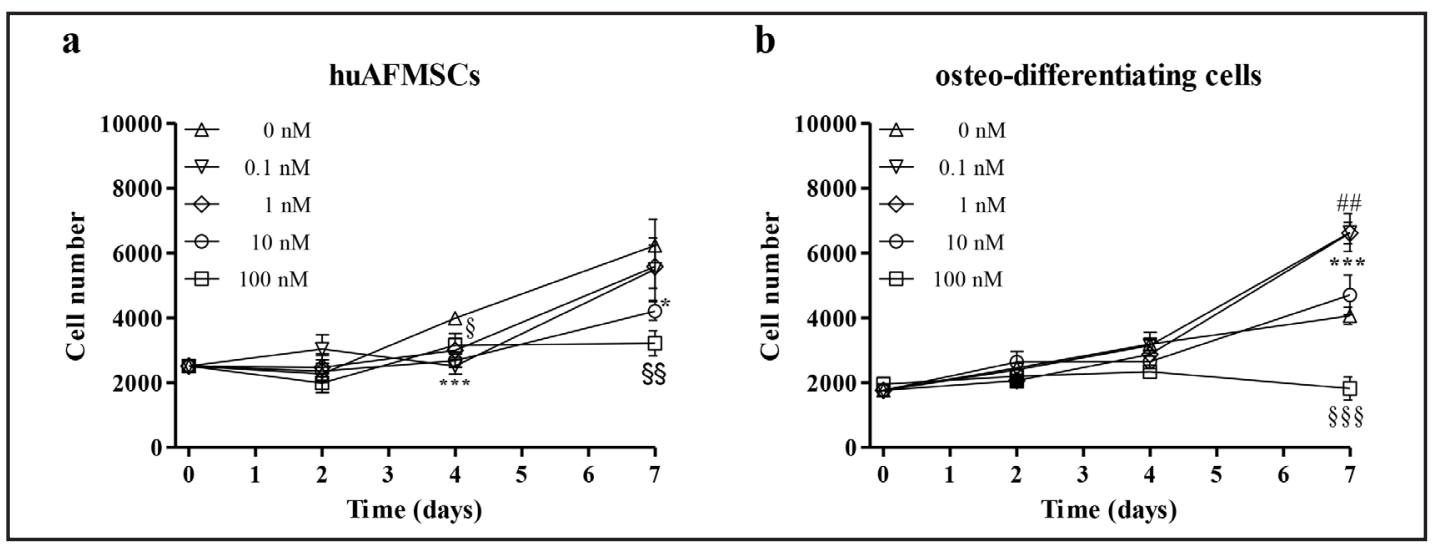

Fig. 5. CT effects on cell proliferation. a, b. Growth curves for the huAFMSCs (a) and osteo-differentiating huAFMSCs (b) treated with different CT concentrations (0-100 nM) for up to 7 days. Data are means \pm S.E.M. from three independent experiments. (a) ${ }^{*} \mathrm{p}<0.05$, ${ }^{* * *} \mathrm{p}<0.001$ for $10 \mathrm{nM} \mathrm{CT}$; ${ }^{\S} \mathrm{p}<0.05$, ${ }^{\S} \mathrm{p}<0.005$ for $100 \mathrm{nM}$ CT vs.=. nM CT. (b) ${ }^{\# \# p ~}<0.05$ for 0.1 nM CT; ${ }^{* * *}$ p $<0.001$ for 1 nM CT; ${ }^{\S \S}$ p $<0.001$ for 100 nM CT vs. 0 nM CT.

decreasing with time) significant increase in the intracellular cAMP levels from $1 \mathrm{~min}$ to 30 min of incubation in the huAFMSCs, and a marked and transient significant increase in cAMP levels at 5 min of incubation in the osteo-differentiated cells (Fig. 3a). In contrast, $100 \mathrm{nM}$ CT induced a transient significant increase in cAMP levels at $5 \mathrm{~min}$ of incubation in the huAFMSCs, and only a small, and not significant, increase in cAMP levels at 5 min of incubation in the osteo-differentiated cells (Fig. 3b).

The intracellular $\mathrm{Ca}^{2+}$ levels were monitored using fluorescence video microscopy and the Fura2-AM fluorescent $\mathrm{Ca}^{2+}$ probe. The data from the image analysis are presented as the mean values of the fluorescence ratio of $340 / 380\left(f_{340 / 380}\right)$ of single Fura2-loaded cells, as a function of time (min). The administration of $1 \mathrm{nM}$ and $100 \mathrm{nM}$ CT induced small and slow increases in the intracellular $\mathrm{Ca}^{2+}$ of the huAFMSCs, and a greater and faster response for the osteo-differentiated cells (Fig. 4a). Of note, only a very small percentage of the cells were responsive to $1 \mathrm{nM}$ CT in terms of these intracellular $\mathrm{Ca}^{2+}$ increases, while this percentage significantly increased when $100 \mathrm{nM}$ CT was added (Fig. 4b). No differences were observed in the cell responsiveness between the huAFMSCs and the osteo-differentiated cell populations (Fig. 4b).

The presence of CT and the activation of its common intracellular signalling pathways led us to investigate possible effects of CT on the biological activities of our cell models. In particular, we determined whether CT can affect cell proliferation or osteogenic potential. 


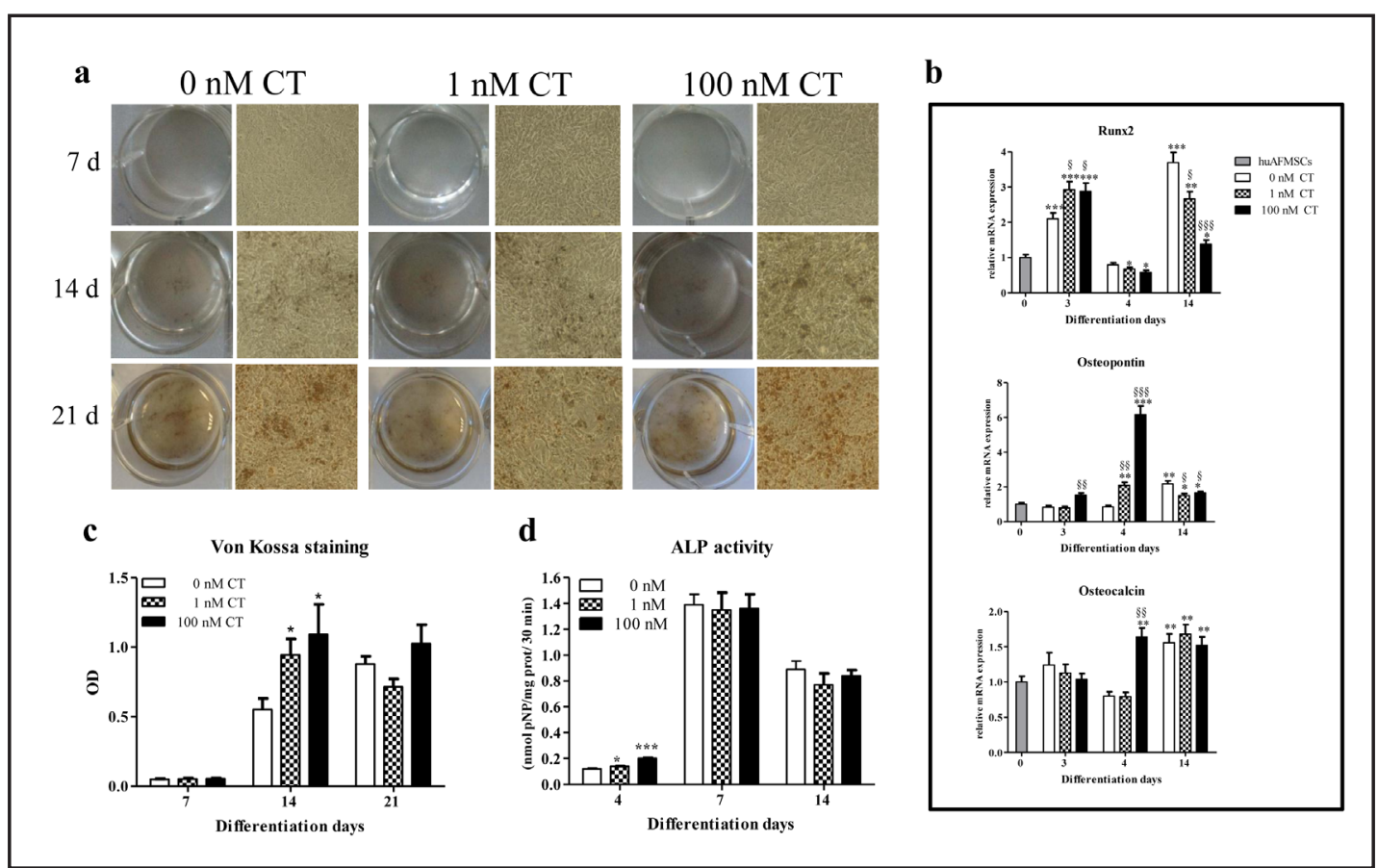

Fig. 6. Effect of calcitonin during osteogenesis. a, c. Representative images (a) of von Kossa staining and corresponding densitometric analyses (c) for huAFMSCs grown in osteo-differentiation medium for 7, 14 and 21 days, without CT ( $0 \mathrm{nM} \mathrm{CT}$ ) and exposed to $1 \mathrm{nM}$ and $100 \mathrm{nM}$ CT. Data are means \pm S.E.M. from three independent experiments. *p<0.05 vs $0 \mathrm{nM} \mathrm{CT}$. b. Quantification of real-time PCR analyses for expression of the osteogenic markers Runx2, osteopontin and osteocalcin in huAFMSCs cultured in undifferentiating or osteogenic conditions for the indicated times. Data are means \pm S.E.M. of three independent experiments with cells from three different donors. Student's t-tests: ${ }^{*} \mathrm{p}<0.05 ;{ }^{* *} \mathrm{p}<0.01 ;{ }^{* * *} \mathrm{p}<0.001$ vs huAFMSCs; ${ }^{\S} \mathrm{p}<0.05$, ${ }^{\S \S} \mathrm{p}<0.01,{ }^{\S \S} \mathrm{p}<0.001$ vs $0 \mathrm{nM}$ CT. $d$. Quantification of ALP activity for huAFMSCs grown in differentiation medium for 4, 7 and 14 days, without CT and exposed to $1 \mathrm{nM}$ and $100 \mathrm{nM}$ CT. Data are means \pm S.E.M. from three independent experiments. ${ }^{*} \mathrm{p}<0.05,{ }^{* * *} \mathrm{p}<0.001$ vs 0 nM CT.

Cell proliferation was monitored over a 7-day period in growth medium in the presence of $0 \mathrm{nM}, 0.1 \mathrm{nM}, 1 \mathrm{nM}, 10 \mathrm{nM}$ and $100 \mathrm{nM}$ CT. The huAFMSCs showed a slow proliferation rate, with a doubling time of about 5-6 days (Fig. 5a). CT induced dose-dependent inhibitory effects on this cell growth. This inhibitory effect of CT became statistically significant on day 4 with $10 \mathrm{nM} \mathrm{CT}$ ( $\mathrm{p}<0.001$ vs. $0 \mathrm{nM} \mathrm{CT}$ ) and $100 \mathrm{nM} \mathrm{CT} \mathrm{(p<0.05} \mathrm{vs} 0 \mathrm{nM} \mathrm{CT})$, and the cytostatic effects induced by CT were evident up to the day 7, both at $10 \mathrm{nM} \mathrm{CT}$ ( $\mathrm{p}<0.05$ vs. 0 nM CT) and 100 nM CT ( $\mathrm{p}<0.01$ vs 0 nM CT) (Fig. 5a).

When cell proliferation was assayed for the cells incubated in the osteogenic medium, the proliferation rate of the control cells (no CT added, $0 \mathrm{nM} \mathrm{CT}$ ) showed a doubling time of about 7 days. Under these experimental conditions $0.1 \mathrm{nM}$ and $1 \mathrm{nM}$ CT significantly increased cell proliferation on day 7, in comparison to the control cells $(p<0.01, p<0.001$ vs.0 $\mathrm{nM}$ CT, respectively), whereas a significant anti-proliferative effect was observed for these cells with $100 \mathrm{nM} \mathrm{CT} \mathrm{(}<<0.001$ vs.0 nM CT) (Fig. 5b).

The effects of CT during osteogenic differentiation of these huAFMSCs were also examined by determining the mineralisation of the cell cultures (i.e., von Kossa staining), the expression of some specific markers of osteogenesis (i.e., Runx2, osteopontin, osteocalcin), and ALP activity with the addition of $1 \mathrm{nM}$ and $100 \mathrm{nM}$ CT.

At 14 and 21 days in osteogenic medium, the cell monolayers showed increased levels of black nodules upon von Kossa staining, with respect to the 7-day cultures (Fig. 6a). CT significantly increased these mineral deposits only in the cells incubated with the osteogenic medium for 14 days (Fig. 6c). 
Real-time PCR assays showed that the expression of the early osteogenic transcription marker Runx2 was significantly increased in the osteo-differentiating cells, with two main peaks of expression at 3 days and 14 days along the differentiation process. This behavior was consistent with the expression of the later osteogenic markers osteopontin and osteocalcin. Compared to the non-differentiated cells at day 0 , the expression of osteopontin and that of the osteocalcin were significantly increased at 14 days after induction towards osteogenic differentiation. Cell exposure to CT (depending on CT concentration) significantly enhanced Runx2 expression at day 3 and osteopontin and osteocalcin expression levels at day 4 of cell differentiation. Of note, CT caused a secondary significant decrease in the expression of Runx2 and osteopontin at day 14 (Fig. 6b).

Interestingly, at day 4, $1 \mathrm{nM} \mathrm{CT}$, and even more $100 \mathrm{nM} \mathrm{CT}$, significantly increased ALP activity in comparison to the control differentiating cells ( $0 \mathrm{nM} \mathrm{CT})(\mathrm{p}<0.05, \mathrm{p}<0.001 \mathrm{vs.0} \mathrm{nM}$ CT, respectively). This early difference was no longer evident after 7 and 14 days of incubation (Fig. 6d). At longer incubation times, CT did not modify ALP activity in comparison to the control cells (Fig. 6d).

\section{Discussion}

In the last decades, there are more and more evidences showing that many different stimuli (physical and chemical) can influence the biology of mesenchymal stem cells of different origin, so potentially affecting tissue repair and regeneration [40-48].

The regeneration of adult tissue depends on the combined actions of multiple signals that commit adult stem cells to lineage-specific differentiation. For bone tissue, these signals include hormones, growth factors and mechanical forces, with CT as one of the endocrine signals that is involved in the bone formation/resorption balance. CT mainly acts on osteoclasts [15], but it has also been reported to have effects on osteoblasts and osteocytes $[16,19]$.

Calcitonins have been isolated from many species, and similarly, the known CTRs can be expressed in different tissue-specific and species-specific isoforms [49]. The human CTR isoform has similar relative potencies in response to different CT peptides; however, there are some differences between the different CTs. In particular, the interactions of salmon and human CT with human CTR induce similar levels of cAMP production, while human CT has a three to tenfold lower affinity in competition binding studies [50-52].

Stem cells have been proposed, and are now used, for bone repair and regeneration, and the cocktail of molecules present in the microenvironment of the engraftment contains the important factors that contribute to successful engraftment [2, 3, 53]. Growing evidence has also demonstrated the commitment of huAFMSCs towards osteogenesis, thus also supporting the use of huAFMSCs in regenerative medicine. The present study was thus aimed to determine whether at the nanomolar concentrations, that are known to activate human CTR [49], human CT can induce biological effects on non-differentiated and osteodifferentiating huAFMSCs.

Both huAFMSCs and osteo-differentiated cells express the human CTR isoform that was previously identified also in osteoclasts and chondrocytes, and that is consistent with the non-glycosylated (about $60 \mathrm{kDa}$ ) and glycosylated (about $80 \mathrm{kDa}$ ) CTR forms [39, 54]. This post-translational glycosylation of the CTR is important for CT binding, and consequently for the activation of the CTR [39]. In our cell models, the glycosylated CTR was expressed, although it was at significantly lower levels in comparison to the non-glycosylated CTR. In addition, the immunostaining data showed that most of the immunofluorescent signal was confined within the cells, with sporadic specific signals seen towards the plasmamembrane. Consistent with these data, we can hypothesise that our cell models express the functional CTR in its glycosylated form with a membrane localisation.

Nanomolar concentrations of CT induced increases in intracellular cAMP and $\mathrm{Ca}^{2+}$ levels in both the huAFMSCs and the osteo-differentiated cells. The CT-induced increase in cAMP 
formation was seen during the early minutes of incubation, and the timing of the responses were dependent on the differentiation status of the cells and the CT concentration. For the low CT concentration ( $1 \mathrm{nM}$ ) this was efficacious within the first minutes of incubation in the huAFMSCs and in the osteo-differentiated cells, in its action as a CTR agonist, as previously described [55]. In contrast, the high CT concentration (100 nM) induced a slower response in the huAFMSCs and had no effect in the osteo-differentiated cells, possibly due to a dosedependent desensitisation process on the CTR.

The CT-induced $\mathrm{Ca}^{2+}$ increase was lower in the huAFMSCs compared to the $\mathrm{Ca}^{2+}$ spike that was seen for the osteo-differentiated cells, while the cell responsiveness was comparable in these two cell phenotypes: when the cells were exposed to $1 \mathrm{nM} \mathrm{CT}$, the percentages of responsive cells were very low, and increased significantly (although remained under 20\%) when the cells were challenged with $100 \mathrm{nM} \mathrm{CT}$.

These data suggested that multiple cellular pathways are activated by CT and possibly triggered by the CTR, although also potentially not excluding other receptor systems. These early effects might be the trigger-point of the biological cell response to CT. The same nanomolar concentrations of CT that can activate different signal transduction pathways induced inhibitory dose-dependent effects on the proliferation of the non-differentiated huAFMSC. These inhibitory effects might be due to a balance between cell proliferation and cell death, with a limited increase in the number of living cells, although a real cytostatic effect cannot be excluded also considering that the cells incubated with CT did not show any features of stress or any cell debris in the medium (data not shown).

The CT-induced inhibitory effect on cell proliferation has been well documented in the osteoclast phenotype, while CT-induced effects on osteoblasts and osteoblast-like cells have been different and sometimes contradictory [17, 19, 24]. CT inhibits bone resorption by inducing a reduction in the cell motility and retraction of osteoclasts [56], and chronic administration of CT reduces the number of osteoclasts [57]. CT has also been shown to directly affect osteoblast proliferation and secretory activity [58], and might also prevent osteoblast and osteocyte apoptosis [23], although again, this action remains controversial. We can speculate that under our experimental conditions, CT might condition the cells, thus preparing them for their commitment to differentiate.

When CT was administered to the cells incubated in the osteogenic medium, the low CT concentration $(1 \mathrm{nM})$ increased the cell proliferation rate, while the high CT concentration $(100 \mathrm{nM})$ resulted in the same anti-proliferative effects seen in the growth medium. This suggests that lower CT concentrations activate cAMP, and consequently PKA, which would support an osteogenesis process and a trophic effect on the osteo-differentiating cells. On the other hand, the high CT concentration appeared to have less specific effects, as it had a weaker effect on cAMP production in the huAFMSCs and no effect on the osteo-differentiated cells; in addition, in both cell models, the high CT increased the number of cells that showed intracellular $\mathrm{Ca}^{2+}$ increases, which probably triggered cytostatic effects independent of the medium composition.

In-vitro studies have indicated that CT can modulate the expression of markers of the osteoblastic phenotype, such as ALP activity and collagen synthesis, in cell lines derived from chick calvaria [59], in transformed murine calvaria cell lines [20,60,61], in human osteosarcoma cells [22], and in normal human bone cells [58]. In our cell models, nanomolar concentrations of CT induced dose-dependent increases in ALP activity in the osteodifferentiating medium at 4 days of incubation. This might represent a critical point for cell commitment towards osteogenesis, starting from which the pro-proliferative and cytostatic effects became evident for the low and high CT concentrations, respectively. At longer incubation times (i.e., 7 and 14 days), the ALP activity was not influenced by the CT in the osteo-differentiated cells. This might be due to the achievement of complete cellular osteodifferentiation, although a homologous desensitisation effect of CT cannot be excluded, also considering that this has been documented for other cell types $[49,62]$. Altogether these data are in agreement with those related to the effects induced by CT on mineral deposits, as revealed by the von Kossa staining here, and gene expression of early and late osteogenic 
markers. In all of these experimental approaches, CT appears to have promoted the osteogenic processes, while at the late incubation times it showed inhibitory or no effects.

Runx2 is an early transcription factor involved in the production of bone matrix promoting the gene expression of proteins such as osteopontin and osteocalcin [63-66]. The time course of the expression of osteogenic markers is related to the presence of external factors but also to the progression and maturation of the osteogenic process itself. Indeed, during bone development, up-regulation of Runx2 is required to induce osteoblast differentiation, whereas Runx2 expression has to be down-regulated for reaching mature osteoblasts forming mature bone [64]. It was proposed that the onset and progression of matrix mineralization processes might be responsible for the down-regulation of genes expressed by mature osteoblasts during the same processes of extracellular matrix maturation and organization [66]. In this scenario, CT plays its role of pro-osteogenic stimulus that promotes the differentiative process probably by resulting in advance of the timing of some osteogenic markers, thus triggering the up- and down-regulation of Runx2 and, consequently, influencing osteopontin and osteocalcin.

As, at present, the occurrence, expression, regulation and physiological significance of the CTR remain largely not fully understood, the data presented here open a new scenario on the potentiality of the CT in these huAFMSCs. We have demonstrated that in these cells, CT can activate intracellular signalling that leads to the control of cell proliferation in the undifferentiated huAFMSCs and enhances the osteogenic markers in the early phases of the osteo-differentiation process. This was accompanied by pro-proliferative or cytostatic effects on osteoblast-like/osteocyte-like cells at longer periods in the osteo-differentiating medium.

These findings open important issues that indicate these cells as a functional target of CT, and possibly of other functional peptides that belong to the CT family. The presence and the modulation of the CTR has been found in many tissues [67] other than in bone cells, and the CTR is not only involved in CT/parathyroid-hormone-regulated calcium balance, but also in the processes of cell growth, cell differentiation and tissue development $[24,68,69]$. Interestingly, when co-expressed with receptor-activity-modifying proteins, the human CTR also acts as a receptor for other regulatory factors of the CT family, such as amylin [70]; moreover, Bouschet and co-workers showed that receptor-activity-modifying proteins also interact with the calcium-sensing receptor to modulate its targeting to the cell membrane [71]. Of note, huAFMSCs express a calcium-sensing receptor where its activation has a central role in cell osteogenesis [34]. This enhances the hypothesis of synergistic effects of receptor expression patterns that can be activated by a cocktail of factors that trigger cell destiny and behaviour.

Although further investigations are necessary not only to detail the mechanisms of action of CT in these cell model, but also to define its function during in vivo transplantation and engraftment of these cells, our data lead the way to the opening of new lines of research on the effects of physiological trophic factors, such as the molecules that belong to the CT family and that have synergic potential in osteogenesis induced on amniotic fluid-derived mesenchymal stem cells.

This is an interesting field for further exploration and it promised to add new insights into both cell therapies and the pharmacological uses of these molecules.

\section{Disclosure Statement}

The authors have no conflicts of interest or financial ties to disclose.

\section{Acknowledgments}

This study was partially supported by a grant to the StemTeCh Group from the CarichietiFoundation, and also by funds to M.A.M. from 'G. d'Annunzio' University of ChietiPescara.

\section{KARGER}




\section{Cellular Physiology Cell Physiol Biochem 2015;36:259-273

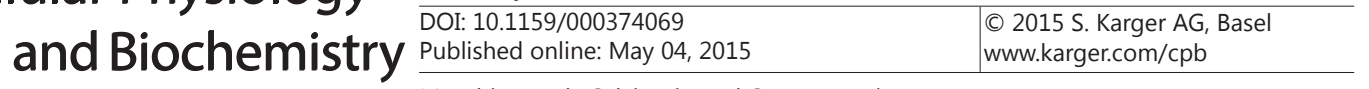 \\ Morabito et al.: Calcitonin and Osteogenesis}

\section{References}

1 Horwitz EM: Stem cell plasticity: The growing potential of cellular therapy. Arch Med Res 2003;34:600-606.

2 Mundra V, Gerling IC, Mahato RI: Mesenchymal stem cell-based therapy. Mol Pharm 2013;10:77-89.

3 Fakhry M, Hamade E, Badran B, Buchet R, Magne D: Molecular mechanisms of mesenchymal stem cell differentiation towards osteoblasts. World J Stem Cells 2013;5:136-148.

4 Granero-Molto F, Weis JA, Longobardi L, Spagnoli A: Role of mesenchymal stem cells in regenerative medicine: Application to bone and cartilage repair. Expert Opin Biol Ther 2008;8:255-268.

5 Waese EY, Kandel RA, Stanford WL: Application of stem cells in bone repair. Skeletal Radiol 2008;37:601608.

6 Kang NH, Hwang KA, Kim SU, Kim YB, Hyun SH, Jeung EB, Choi KC: Potential antitumor therapeutic strategies of human amniotic membrane and amniotic fluid-derived stem cells. Cancer Gene Ther 2012;19:517-522.

7 Zheng YB, Gao ZL, Xie C, Zhu HP, Peng L, Chen JH, Chong YT: Characterization and hepatogenic differentiation of mesenchymal stem cells from human amniotic fluid and human bone marrow: A comparative study. Cell Biol Int 2008;32:1439-1448.

8 D'Alimonte I, Lannutti A, Pipino C, Di Tomo P, Pierdomenico L, Cianci E, Antonucci I, Marchisio M, Romano M, Stuppia L, Caciagli F, Pandolfi A, Ciccarelli R: Wnt signaling behaves as a "Master regulator" In the osteogenic and adipogenic commitment of human amniotic fluid mesenchymal stem cells. Stem Cell Rev 2013;9:642-654.

9 De Coppi P, Bartsch G, Jr., Siddiqui MM, Xu T, Santos CC, Perin L, Mostoslavsky G, Serre AC, Snyder EY, Yoo JJ, Furth ME, Soker S, Atala A: Isolation of amniotic stem cell lines with potential for therapy. Nat Biotechnol 2007;25:100-106.

10 Maraldi T, Riccio M, Pisciotta A, Zavatti M, Carnevale G, Beretti F, La Sala GB, Motta A, De Pol A: Human amniotic fluid-derived and dental pulp-derived stem cells seeded into collagen scaffold repair critical-size bone defects promoting vascularization. Stem Cell Res Ther 2013;4:53.

11 Rodrigues MT, Lee BK, Lee SJ, Gomes ME, Reis RL, Atala A, Yoo JJ: The effect of differentiation stage of amniotic fluid stem cells on bone regeneration. Biomaterials 2012;33:6069-6078.

12 Shaw SW, David AL, De Coppi P: Clinical applications of prenatal and postnatal therapy using stem cells retrieved from amniotic fluid. Curr Opin Obstet Gynecol 2011;23:109-116.

13 Carter PH, Schipani E: The roles of parathyroid hormone and calcitonin in bone remodeling: Prospects for novel therapeutics. Endocr Metab Immune Disord Drug Targets 2006;6:59-76.

14 Inzerillo AM, Zaidi M, Huang CL: Calcitonin: Physiological actions and clinical applications. J Pediatr Endocrinol Metab 2004;17:931-940.

15 Del Fattore A, Teti A, Rucci N: Osteoclast receptors and signaling. Arch Biochem Biophys 2008;473:147160.

16 Davey RA, Findlay DM: Calcitonin: Physiology or fantasy? J Bone Miner Res 2013;28:973-979.

17 Zaidi M, Moonga BS, Abe E: Calcitonin and bone formation: A knockout full of surprises. J Clin Invest 2002;110:1769-1771.

18 Villa I, Dal Fiume C, Maestroni A, Rubinacci A, Ravasi F, Guidobono F: Human osteoblast-like cell proliferation induced by calcitonin-related peptides involves pkc activity. Am J Physiol Endocrinol Metab 2003;284:E627-633.

19 Wallach S, Farley JR, Baylink DJ, Brenner-Gati L: Effects of calcitonin on bone quality and osteoblastic function. Calcif Tissue Int 1993;52:335-339.

20 Farley JR, Hall SL, Tarbaux NM: Calcitonin (but not calcitonin gene-related peptide) increases mouse bone cell proliferation in a dose-dependent manner, and increases mouse bone formation, alone and in combination with fluoride. Calcif Tissue Int 1989;45:214-221.

21 Farley JR, Hall SL, Herring S: Calcitonin acutely increases net 45ca uptake and alters alkaline phosphatase specific activity in human osteosarcoma cells. Metabolism 1993;42:97-104.

22 Farley JR, Wergedal JE, Hall SL, Herring S, Tarbaux NM: Calcitonin has direct effect on 3[h]-thymidine incorporation and alkaline phosphatase activity in human osteoblast-line cell. Calcif Tissue Int 1991;48:297-301.

23 Plotkin LI, Weinstein RS, Parfitt AM, Roberson PK, Manolagas SC, Bellido T: Prevention of osteocyte and osteoblast apoptosis by bisphosphonates and calcitonin. J Clin Invest 1999;104:1363-1374.

24 Naot D, Cornish J: The role of peptides and receptors of the calcitonin family in the regulation of bone metabolism. Bone 2008;43:813-818.

25 Sexton PM, Findlay DM, Martin TJ: Calcitonin. Curr Med Chem 1999;6:1067-1093. 


\section{Cellular Physiology Cell Physiol Biochem 2015;36:259-273 \begin{tabular}{l|l|l} 
DOI: 10.1159/000374069 & C 2015 S. Karger AG, Basel
\end{tabular} and Biochemistry Published online: May 04, 2015 \\ Morabito et al:: Calcitonin and Osteogenesis}

26 Force T, Bonventre JV, Flannery MR, Gorn AH, Yamin M, Goldring SR: A cloned porcine renal calcitonin receptor couples to adenylyl cyclase and phospholipase c. Am J Physiol 1992;262:F1110-1115.

27 Pondel M: Calcitonin and calcitonin receptors: Bone and beyond. Int J Exp Pathol 2000;81:405-422.

28 Granholm S, Lundberg P, Lerner UH: Expression of the calcitonin receptor, calcitonin receptor-like receptor, and receptor activity modifying proteins during osteoclast differentiation. J Cell Biochem 2008;104:920933.

29 Trubiani O, Fulle S, Traini T, Paludi M, la Rovere R, Orciani M, Caputi S, Piattelli A: Functional assay, expression of growth factors and proteins modulating bone-arrangement in human osteoblasts seeded on an anorganic bovine bone biomaterial. Eur Cell Mater 2010;20:72-83.

30 Farley JR, Hall SL, Herring S, Tarbaux NM: Two biochemical indices of mouse bone formation are increased, in vivo, in response to calcitonin. Calcif Tissue Int 1992;50:67-73.

31 Forrest SM, Ng KW, Findlay DM, Michelangeli VP, Livesey SA, Partridge NC, Zajac JD, Martin TJ: Characterization of an osteoblast-like clonal cell line which responds to both parathyroid hormone and calcitonin. Calcif Tissue Int 1985;37:51-56.

32 Iida-Klein A, Yee DC, Brandli DW, Mirikitani EJ, Hahn TJ: Effects of calcitonin on 3',5'-cyclic adenosine monophosphate and calcium second messenger generation and osteoblast function in umr 106-06 osteoblast-like cells. Endocrinology 1992;130:381-388.

33 Villa I, Mrak E, Rubinacci A, Ravasi F, Guidobono F: Cgrp inhibits osteoprotegerin production in human osteoblast-like cells via camp/pka-dependent pathway. Am J Physiol Cell Physiol 2006;291:C529-537.

34 Pipino C, Di Tomo P, Mandatori D, Cianci E, Lanuti P, Cutrona MB, Penolazzi L, Pierdomenico L, Lambertini E, Antonucci I, Sirolli V, Bonomini M, Romano M, Piva R, Marchisio M, Pandolfi A: Calcium sensing receptor activation by calcimimetic $r-568$ in human amniotic fluid mesenchymal stem cells: Correlation with osteogenic differentiation. Stem Cells Dev 2014

35 Guarnieri S, Morabito C, Paolini C, Boncompagni S, Pilla R, Fanò-Illic G, Mariggiò MA: Growth associated protein 43 is expressed in skeletal muscle fibers and is localized in proximity of mitochondria and calcium release units. PLoS One 2013;8:e53267.

36 Corset V, Nguyen-Ba-Charvet KT, Forcet C, Moyse E, Chedotal A, Mehlen P: Netrin-1-mediated axon outgrowth and camp production requires interaction with adenosine a2b receptor. Nature 2000;407:747750 .

37 Orciani M, Morabito C, Emanuelli M, Guarnieri S, Sartini D, Giannubilo SR, Di Primio R, Tranquilli AL, Mariggiò MA: Neurogenic potential of mesenchymal-like stem cells from human amniotic fluid: The influence of extracellular growth factors. J Biol Regul Homeost Agents 2011;25:115-130.

38 Mariggiò MA, Guarnieri S, Mariggiò S, Morabito C, Gianfranceschi GL, Fanò G: N-cam expression and localization in pc12 cells modulated by extracellular peptides. Peptides 2002;23:2151-2161.

39 Ho HH, Gilbert MT, Nussenzveig DR, Gershengorn MC: Glycosylation is important for binding to human calcitonin receptors. Biochemistry 1999;38:1866-1872.

40 Chen X, Luther G, Zhang W, Nan G, Wagner ER, Liao Z, Wu N, Zhang H, Wang N, Wen S, He Y, Deng F, Zhang J, Wu D, Zhang B, Haydon RC, Zhou L, Luu HH, He TC: The e-f hand calcium-binding protein s100a4 regulates the proliferation, survival and differentiation potential of human osteosarcoma cells. Cell Physiol Biochem 2013;32:1083-1096.

41 Chen Y, Chen L, Yin Q, Gao H, Dong P, Zhang X, Kang J: Reciprocal interferences of tnf-alpha and wnt1/ beta-catenin signaling axes shift bone marrow-derived stem cells towards osteoblast lineage after ethanol exposure. Cell Physiol Biochem 2013;32:755-765.

42 Chen Y, Gao H, Yin Q, Chen L, Dong P, Zhang X, Kang J: Er stress activating atf4/chop-tnf-alpha signaling pathway contributes to alcohol-induced disruption of osteogenic lineage of multipotential mesenchymal stem cell. Cell Physiol Biochem 2013;32:743-754.

43 Gao W, Zhang H, Chang G, Xie Z, Wang H, Ma L, Han Z, Li Q Pang T: Decreased intracellular ph induced by cariporide differentially contributes to human umbilical cord-derived mesenchymal stem cells differentiation. Cell Physiol Biochem 2014;33:185-194.

44 Hernandez-Bule ML, Paino CL, Trillo MA, Ubeda A: Electric stimulation at $448 \mathrm{khz}$ promotes proliferation of human mesenchymal stem cells. Cell Physiol Biochem 2014;34:1741-1755.

45 Hu N, Wang C, Liang X, Yin L, Luo X, Liu B, Zhang H, Shui W, Nan G, Wang N, Wu N, Chen X, He Y, Wen S, Deng F, Liao Z, Luu HH, Haydon RC, He TC, Huang W: Inhibition of histone deacetylases potentiates bmp9induced osteogenic signaling in mouse mesenchymal stem cells. Cell Physiol Biochem 2013;32:486-498.

46 Rodrigues MT, Leonor IB, Groen N, Viegas CA, Dias IR, Caridade SG, Mano JF, Gomes ME, Reis RL: Bone marrow stromal cells on a three-dimensional bioactive fiber mesh undergo osteogenic differentiation in the absence of osteogenic media supplements: The effect of silanol groups. Acta Biomater 2014;10:4175- 


\section{Cellular Physiology Cell Physiol Biochem 2015;36:259-273

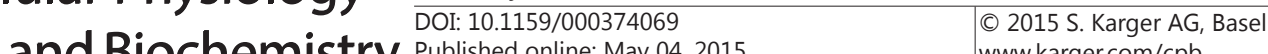 \\ Morabito et al:: Calcitonin and Osteogenesis}

4185.

47 Stockl S, Gottl C, Grifka J, Grassel S: Sox9 modulates proliferation and expression of osteogenic markers of adipose-derived stem cells (asc). Cell Physiol Biochem 2013;31:703-717.

48 Wojakowski W, Tendera M: Mobilization of bone marrow-derived progenitor cells in acute coronary syndromes. Folia Histochem Cytobiol 2005;43:229-232.

49 Purdue BW, Tilakaratne N, Sexton PM: Molecular pharmacology of the calcitonin receptor. Receptors Channels 2002;8:243-255.

50 Hilton JM, Dowton M, Houssami S, Sexton PM: Identification of key components in the irreversibility of salmon calcitonin binding to calcitonin receptors. J Endocrinol 2000;166:213-226.

51 Houssami S, Findlay DM, Brady CL, Martin TJ, Epand RM, Moore EE, Murayama E, Tamura T, Orlowski RC, Sexton PM: Divergent structural requirements exist for calcitonin receptor binding specificity and adenylate cyclase activation. Mol Pharmacol 1995;47:798-809.

52 Kuestner RE, Elrod RD, Grant FJ, Hagen FS, Kuijper JL, Matthewes SL, O'Hara PJ, Sheppard PO, Stroop SD, Thompson DL, et al.: Cloning and characterization of an abundant subtype of the human calcitonin receptor. Mol Pharmacol 1994;46:246-255.

53 Jones E, Yang X: Mesenchymal stem cells and bone regeneration: Current status. Injury 2011;42:562-568.

54 Segovia-Silvestre T, Bonnefond C, Sondergaard BC, Christensen T, Karsdal MA, Bay-Jensen AC: Identification of the calcitonin receptor in osteoarthritic chondrocytes. BMC Res Notes 2011;4:407.

55 Eilon G, Perkins J, Viola MV: Characteristics of a calcitonin-responsive cell line derived from a human osteosarcoma. Cancer Res 1983;43:3763-3769.

56 Moonga BS, Alam AS, Bevis PJ, Avaldi F, Soncini R, Huang CL, Zaidi M: Regulation of cytosolic free calcium in isolated rat osteoclasts by calcitonin. J Endocrinol 1992;132:241-249.

57 Becker KL, Muller B, Nyle'n ES, Cohen R, White JC, Snider RHJ: Calcitonin gene family of peptides. Structure, molecularbiology,and effects. . San Diego, CA San Diego Academic Press, 2002.

58 Farley J, Dimai HP, Stilt-Coffing B, Farley P, Pham T, Mohan S: Calcitonin increases the concentration of insulin-like growth factors in serum-free cultures of human osteoblast-line cells. Calcif Tissue Int 2000;67:247-254.

59 Farley JR, Tarbaux NM, Hall SL, Linkhart TA, Baylink DJ: The anti-bone resorptive agent calcitonin also acts in vitro to directly increase bone formation and bone cell proliferation. Endocrinology 1988;123:159-167.

60 Ito N, Yamazaki H, Nakazaki M, Miyahara T, Kozuka H, Sudo H: Response of osteoblastic clonal cell line (mc3t3-e1) to [asu]eel calcitonin at a specific cell density or differentiation stage. Calcif Tissue Int 1987;40:200-205.

61 Kobayashi T, Sugimoto T, Saijoh K, Fukase M, Chihara K: Calcitonin directly acts in mouse osteoblastic mc 3t3-e1 cells to stimulate mrna expression of c-fos, insulin-like growth factor-1 and osteoblastic phenotype (type 1 collagen and osteocalcin). Biochem Biophys Res Commun 1994;199:876-880.

62 Wada S, Udagawa N, Nagata N, Martin TJ, Findlay DM: Calcitonin receptor down-regulation relates to calcitonin resistance in mature mouse osteoclasts. Endocrinology 1996;137:1042-1048.

63 Komori T: Regulation of osteoblast differentiation by runx2. Adv Exp Med Biol 2010;658:43-49.

64 Komori T: Regulation of bone development and extracellular matrix protein genes by runx2. Cell Tissue Res 2010;339:189-195.

65 Komori T, Yagi H, Nomura S, Yamaguchi A, Sasaki K, Deguchi K, Shimizu Y, Bronson RT, Gao YH, Inada M, Sato M, Okamoto R, Kitamura Y, Yoshiki S, Kishimoto T: Targeted disruption of cbfa1 results in a complete lack of bone formation owing to maturational arrest of osteoblasts. Cell 1997;89:755-764.

66 Neve A, Corrado A, Cantatore FP: Osteoblast physiology in normal and pathological conditions. Cell Tissue Res;343:289-302.

67 Cafforio P, De Matteo M, Brunetti AE, Dammacco F, Silvestris F: Functional expression of the calcitonin receptor by human $t$ and b cells. Hum Immunol 2009;70:678-685.

68 Wang J, Rout UK, Bagchi IC, Armant DR: Expression of calcitonin receptors in mouse preimplantation embryos and their function in the regulation of blastocyst differentiation by calcitonin. Development 1998;125:4293-4302.

69 Wookey PJ: A review of calcitonin receptor expression in embryonic, foetal and adult tissues, with an hypothesis on the connection between expression during foetal development and disease. The Open Zoology Journal 2009;2:53-61.

70 Fischer JA, Muff R, Born W: Functional relevance of g-protein-coupled-receptor-associated proteins, exemplified by receptor-activity-modifying proteins (ramps). Biochem Soc Trans 2002;30:455-460.

71 Bouschet T, Martin S, Henley JM: Regulation of calcium sensing receptor trafficking by ramps. Adv Exp Med Biol 2012;744:39-48. 